\begin{tabular}{|c|c|}
\hline Title & Dealing with socioeconomic and climate related uncertainty in small-scale salt producers in rural Sampang, Indonesia \\
\hline Author(s) & Helmi, A Ifian; Sasaoka, Masatoshi \\
\hline Citation & $\begin{array}{l}\text { Journal of rural studies, 59, 88-97 } \\
\text { https://doi.org/10.1016/.jrurstud.2018.02.005 }\end{array}$ \\
\hline Issue Date & 201804 \\
\hline Doc URL & http:/hdl.handle.net/2115/76796 \\
\hline Rights & $\begin{array}{l}\text { (c) 2018, Elsevier. Licensed under the Creative Commons A ttribution-NonCommercial-NoDerivatives } 4.0 \text { International } \\
\text { http://reativecommons.org/icenses/by-nc-nd/4.0/ }\end{array}$ \\
\hline Rights(URL) & http://creativecommons.org/icenses/by-nc-nd/4.0/ \\
\hline Tyре & article (author version) \\
\hline File Information & RURAL_2017_360_v.03_AuthorName.pdf \\
\hline
\end{tabular}

Instructions for use 


\title{
Dealing with socioeconomic and climate-related uncertainty in small- scale salt producers in rural Sampang, Indonesia
}

\author{
Alfian Helmia ${ }^{\mathrm{a}, \mathrm{b}, 1}$, Masatoshi Sasaoka ${ }^{\mathrm{a}}$ \\ ${ }^{a}$ Department of Human Sciences, Graduate School of Letters, Hokkaido University, Japan \\ ${ }^{b}$ Department of Communication and Community Development Sciences, Bogor Agricultural University, \\ Indonesia
}

\begin{abstract}
In this study, we aimed to investigate the uncertainty events affecting small-scale salt producers and find out how small-scale salt producers were responding to the combinations of climatic and socioeconomic uncertainty they had experienced. We divided the salt producers into three categories based on land ownership: (1) land owner; (2) wage laborer; and (3) tenant. We examine their perceptions of the problems and their adaptive responses at the household and aggregate levels. Based on fieldwork in salt production areas in rural Sampang, Indonesia. First, we find that, the effect of uncertainty events does affect salt producers unequally. This, depending on resources and power within community. Second, there are advantages and disadvantages of each adaptation. This is representing dilemma of salt producers that shape how adaptation practices are negotiated in order to respond the combinations of climatic and socioeconomic uncertainty. Finally, our finding underlines the challenges of developing an integrated approach to mitigate these uncertainty events.
\end{abstract}

Keywords: adaptation, climate change, rural farm, salt producer, vulnerability

\section{Introduction}

Small-scale salt producers in Sampang, Indonesia have been experiencing unusual extreme weather, volatile price and ambiguity regulation in their everyday life. In 2013, at least 2,950 metric tons of salt were flooded with water because of rain just before harvesting time (BPBD, 2013). In the peak harvest period of 2015, the local price of salt has been dropping because of an abundance of imported salt that had been entering the

\footnotetext{
1 Corresponding author. Department of Human Sciences, Graduate School of Letters, Hokkaido University, Kita 10, Nishi 7, Sapporo 060-0810, Japan.

E-mail addresses: alfianahelmi@gmail.com (A. Helmi), m.sasaoka@let.hokudai.ac.jp (M. Sasaoka).
} 
country during the peak harvest period. Salt prices fell to Rp. 200 per kg from the breakeven fair price of Rp. 500 to Rp. 600 per kg (The Jakarta Post, 2015). More and more, salt production decline by 70 percent because of La Niña and an influx of imported salt in August 2016 (The Jakarta Post, 2016). Successive years of poor or unstable prices and damaging weather combined to pose multiple challenges for salt farmers, who faced the question of how to adapt given uncertainty about future impacts from climatic and socioeconomic variability.

In this study, we aimed to investigate the uncertainty events affecting salt producers and find out how small-scale salt producers were responding to the combinations of climatic and socioeconomic shocks they had experienced in the context of rural Sampang, Indonesia. We examine their perceptions of the problems and their adaptive responses at the household and aggregate levels. We believed that perceptions would be critical in shaping small-scale salt producers' adaptive responses to the stresses outside their previous experiences (see Deressa et al., 2011; Hassan \& Nhemachena, 2008).

Similar to other decision makers, salt producers operate with an expectation of some degree of variability in the climatic conditions for production, and typically have developed a number of strategies to cope with such annual and inter-annual variability (see summary in Agrawal et al., 2008). Nevertheless, climate change may generate changes in production conditions, causing more variable conditions that may begin to exceed the limits of farmers' coping strategies (Smit et al., 2000). If farmers perceive an event as highly anomalous, it may be sufficient to convince them that conditions are changing beyond the bounds of normal variation, and motivate adaptive changes.

Similarly, the risks entailed in engaging in commercial markets may be familiar to salt producers who have traditionally produced salt for domestic markets. However, farmers' exposure to market risks is heavily influenced by the institutional context of production, and often in ways unanticipated by farm households (Eakin, 2000; Leichenko \& O'Brien, 2008). Abrupt changes in market conditions and policy may also represent shocks to farmers' livelihoods, compelling changes in strategy, as well as affecting farmers' capacities to engage in traditional climate risk management practices.

Although uncertainty events have not been well documented, resource-dependent communities such as salt producers are the most vulnerable to the impact of these phenomena. Given the lack of resources and access to technology and finances, smallscale salt producers have limited capacity to develop adaptation strategies to reduce their vulnerability to uncertainty events (Mehar et al., 2016). Consequently, most of them live on the edge of extreme uncertainty, sometimes falling just below and sometimes rising just above the threshold of survival. More and more, adaptive responses will be required 
to cope with a plethora of similar hazards arising as a result of global environmental change (McLean \& Tsyban, 2001). This makes them an important focus for adaptation research.

The literature of adaptation and vulnerability revealed to be key concept in explaining the societal implications of uncertainty events (Füssel \& Klein, 2006; Manyena, 2006). However, vulnerability and adaptation strategies to uncertainty events is usually inversely related to people's ability to access resources, assets and means of protection. Those with limited access to resources usually bear a huge burden of impacts compare to rich people whose ability to respond is high and may be timely in the presence of early warning systems (Brooks et al., 2005). On the other hand, poor people are considered more exposed to it and respond late to it. This, however, depends on many other factors such as context, age, women, gender identity, and people with disabilities, ethnicity and income level (Pelling \& High, 2005; Adger et al., 2007; Adger \& Jordan, 2009). Vulnerability thus reflects how power and wealth are shared within society and traces its roots to cultural, social, economic and political structures, which lie beyond the reach of those who are poor and are comparatively more vulnerable (Blaikie et al., 2005; Brooks et al., 2005). Understanding people's adaptation to climatic and socioeconomic uncertainty through the lens of their vulnerability therefore requires detailed studies relying upon qualitative and quantitative research methods to better reflect the unique realities of people's everyday lives. Exploring those, is this paper's focus of study.

Evidence from other countries suggests that a better understanding of how farmers perceive uncertainty events and the adaptation strategies they practice is needed to make policies and design programs aimed at promoting successful adaptation in the agricultural sector (Deressa et al., 2009; Hassan \& Nhemachena, 2008; Kesa \& Fraiture, 2016). Understanding the uncertainty event and their responses is also crucial to understanding and drawing a road map for future strategies to help the small-scale salt producers cope and manage risks from the policy standpoint. In many OECD countries, policymakers are increasingly seeking to support the resilience of communities and are indicating a need to increase self-reliance and sustainability at the community level (OECD, 2014).

In Indonesia, current national programs for enhancing capacity of salt producers' communities to cope with socioeconomic and climate-related risks and to adapt in response to them have received relatively little attention. Programs for developing and disseminating weather forecasts are limited, while long-term programs for addressing climate variability and climate change have not been well developed (Kurniawan \& Azizi, 2012; Kesa \& Fraiture, 2016). 
Effective policies and programs to address small-scale salt producers' ability to cope and recover from uncertainty events are necessary. To be effective, these programs need to be aligned with small-scale salt producers' views. Hence, this paper provides detailed evidence at the salt producers' level (bottom-up) and discussion to highlight the factual situation of salt producers and their decision environment.

\section{Study area}

This study was conducted in rural Sampang of Madura Island, the second largest salt production area in Indonesia. Sampang is located between $113^{\circ} 08^{\prime}$ and $113^{\circ} 39^{\prime}$ East and $06^{\circ} 05^{\prime}$ and $07^{\circ} 13^{\prime}$ South in East Java Province, Indonesia (Fig. 1). Sampang produces $14 \%$ of total domestic salt production from 4,624 ha of salt pans. The salt pans are divided into a 3,396-ha area (73\%) of owned by individuals and a 1,228-ha (27\%) area owned by state-owned enterprise (KKP, 2015).

Evaporative salt production in rural Sampang occurs during the dry seasons, namely July to October. The production season begins during the southeast monsoon, as salt producers begin collecting seawater in June, July or August. They harvest salt for the first time in August, September or October. The timing of the process depends heavily on weather, as rain lowers salinity and clouds retard evaporation.

The highest rainfall occurs in January and December while August and September has the lowest rainfall in Sampang. Sampang has a very hot and arid climate in summer with a maximum temperature recorded of $34^{\circ} \mathrm{C}$ and minimum temperature recorded of $29^{\circ} \mathrm{C}$. On average, the district receives an annual rainfall of $918 \mathrm{~mm}$ (BPS-Statistics Sampang, 2016).

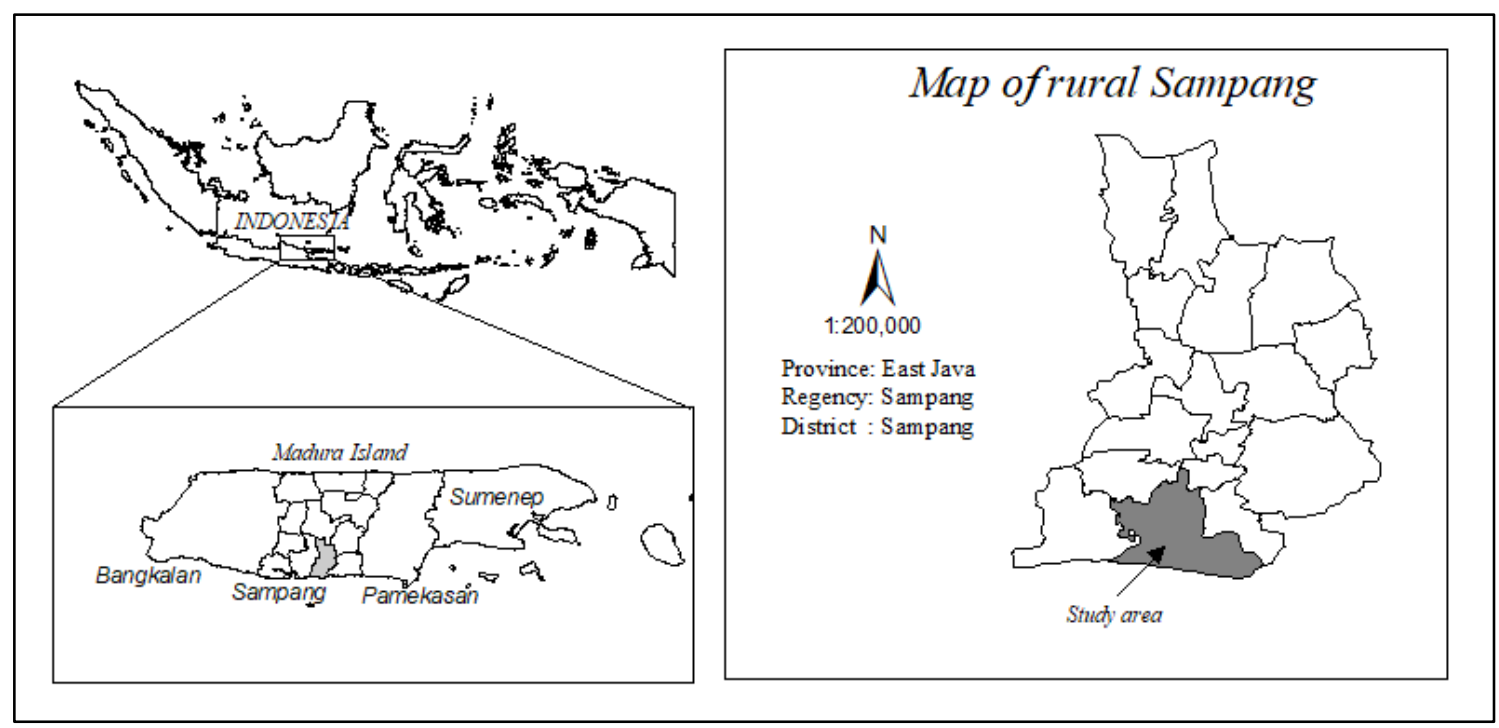

Fig. 1. Map showing the study area from which data were collected 
Sampang was selected for this case study because most the people perform salt farming as their main livelihood and, at the same time, are the most vulnerable to the vagaries of climate, with high dependence on sunshine and elevated poverty levels. As pointed out by Lund (2014), we believe the case study will provide in-depth analysis of the adaptation strategies in small-scale salt producers.

\section{Small-scale salt producers}

Salt production has played an irreplaceable role in the lives of Sampang people. Salt making process is simple but extremely laborious. Based on data from the Department of Marine and Fisheries Sampang, in 2011 at least there are approximately 1,201 people who are involved in salt business activities in Sampang Regency. In addition, as many as 12,738 people become the tenant of community salt ponds who do not own land (DKP Sampang, 2011). During harvest time, the number of tenants will be increased sharply to assist the process of harvesting, transporting and distribution of salt.

Table 1. Total salt production in Indonesia

\begin{tabular}{|c|c|c|c|c|c|c|c|c|}
\hline & \multirow{2}{*}{ Source of production } & \multicolumn{7}{|c|}{ Years of production (x1000 tons) } \\
\hline & & 2010 & 2011 & 2012 & 2013 & 2014 & 2015 & 2016 \\
\hline \multirow[t]{2}{*}{1} & State-owned enterprises & 4.5 & 156.7 & 307.3 & 156.8 & 315 & 345 & 26 \\
\hline & & $14.7 \%$ & $14.1 \%$ & $14.8 \%$ & $14.4 \%$ & $14.4 \%$ & $12.1 \%$ & $18.1 \%$ \\
\hline \multirow[t]{4}{*}{2} & Small-scale salt producers & 26.1 & 956.4 & 1764.3 & 930.9 & 1875 & 2495 & 118 \\
\hline & & $85.3 \%$ & $85.9 \%$ & $85.2 \%$ & $85.6 \%$ & $85.6 \%$ & $87.9 \%$ & $81.9 \%$ \\
\hline & Total salt production & 30.6 & 1113.1 & 2071.6 & 1087.7 & 2190 & 2840 & 144 \\
\hline & & $100 \%$ & $100 \%$ & $100 \%$ & $100 \%$ & $100 \%$ & $100 \%$ & $100 \%$ \\
\hline
\end{tabular}

Source: KKP (2016)

In Indonesian, particularly in Sampang, salt producers are dominated by small-scale salt producers. As can be seen in Table 1, small-scale salt producers contribute to the total salt production more than $80 \%$. This is indicating how important small-scale salt production in terms of national salt supply.

Small-scale farms have figured prominently in the discourse about agricultural development, but definitions are often unclear. Hazell and Rahman (2014) pointed out that the terms smallholder or small farms pay attention to farm size, often denoting those farms that are less than 2 ha in extent. Holding size is perhaps the most direct and easily introduced indicator of who small-scale salt producers are. However, size is not a good criterion for defining small farms. Further, Rigg et al., (2016) pointed out that “...even quite large holdings, made even larger by the opportunities afforded by mechanization, 
may be family-owned and operated; and that smallholders need not be a subordinate class so that size cannot be used as a simple proxy for subordination". Thus, in this study, smallscale salt producers are defined as those producing raw or non-iodized salt on limited land areas. Indeed, they are often defined by their association with risk, vulnerability, marginalization, and exploitation (Adger et al., 2005; Rochwulaningsih, 2017; Bacon, 2005). All of them suffer, in varying degrees, similar problems associated with isolation and low levels of technology, but also unpredictable exposure to world markets (Morton, 2007).

We divided the salt producers into three categories based on land ownership: (1) land owner; (2) wage laborer; and (3) tenant. The term "land owner" refers to a person who owns a salt field. "Wage laborer" refers to a worker who sells his or her labor under a formal or informal employment contract to produce salt. "Tenant" refers to a person whom a land owner allows to use the land (salt field) in return for a share of the salt produced on this portion of land. Land owners are the smallest group, but they earn the most money from the salt farms. In contrast, tenants are the largest group, but they receive less than half of the total earnings.

There are three grades of salt: (i) high grade (salt should be contained at least $94 \%$ of $\mathrm{NaCl}$, pure white color, free of sand and mud); (ii) medium grade (salt should be contained at least $88 \%-94 \%$ of $\mathrm{NaCl}$, white color, impurity of mud and clay contained); (iii) low grade (salt should be contained less than $88 \%$ of $\mathrm{NaCl}$, share of white, impurity of mud and clay contained). For salt manufacturers, imported salt has better quality than local salt. This is because the imported salt is composed of more than $94 \%$ sodium chloride $(\mathrm{NaCl}>94 \%)$, has a brighter color, and is cleaner than local salt. Furthermore, imported salt has already met the Indonesian National Standard (SNI) as a raw material for the iodized salt industry, so that when processed into briquettes or iodized salt it can be packaged and labeled directly. Therefore, even though the imported salt price is higher than the local salt, it is very efficient and inexpensive, thus, the production cost becomes cheaper than local salt. 


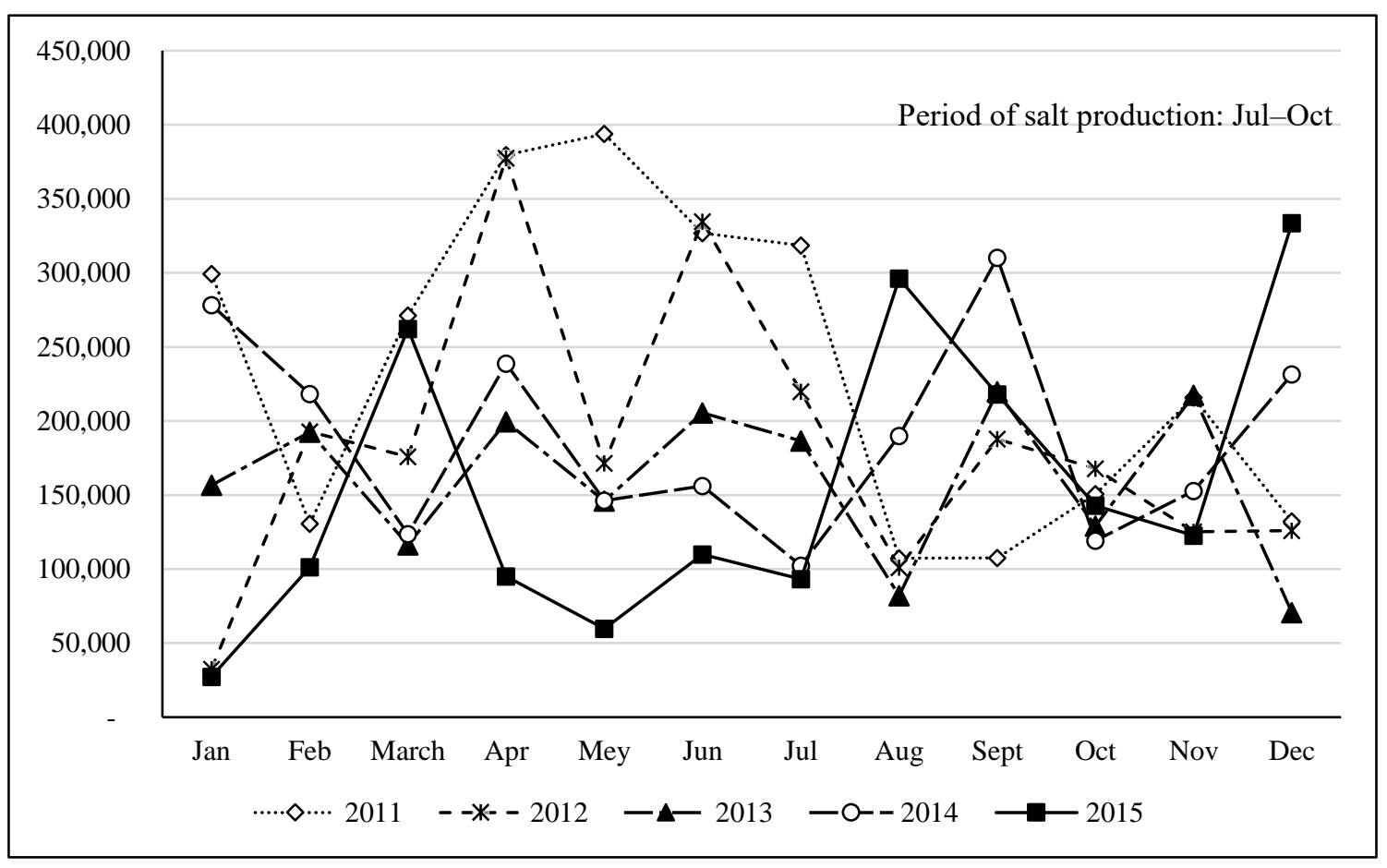

Fig. 2. Monthly average volume of salt import in Indonesia for five years

Source: Ministry of Trade, Republic of Indonesia, 2016

During the period of 2011-2015, on average, Indonesia imported approximately 1.9 million metric tons of salt from Australia, China, India and other countries (Statistics Indonesia 2016). Through the Trade Ministerial Decree No. 125/M-DAG/PER/12/2015, the Indonesian Ministry of Trade provides import licenses to the registered importers (locally called "importir terdaftar") with a free-tariff policy for imported salt. As a result, imports became easier because this regulation makes no restrictions on imported salt during the peak harvest season or on the standard of national purchasing price (harga patokan garam), and there are no obligations for importers to purchase salt from local salt producers.

\section{Methods}

\subsection{Data collection}

This research employed a mix of quantitative and qualitative methods of data collection. A quantitative method -household survey questionnaire- was used to analyze the implication of uncertainty for small-scale salt producers and to identify the factors that influence the salt mining conditions. Qualitative methods -key informant interviews, focus group discussion (FGD) and participatory observation- were also used to gain a deeper understanding o0f socioeconomic issues and to identify the adaptation techniques 
employed by small-scale salt producers to minimize impacts of such uncertainties. Primary data collection was done between September 2015 and May 2016. The research team administered all questionnaires personally.

Information collected during household surveys include: (1) small-scale salt producers' perceptions on the frequency and effects of exposure to uncertain weather conditions, fluctuations in price, changing government regulation and natural disasters; and (2) the strategies undertaken by small-scale salt producers' in order to minimizing uncertainty. Key informant interviews are used to collect data from some stakeholders, such as the head of village, public officials (Marine and Fisheries officers), and the leader of associations or groups like salt producer association and managers of the state-owned enterprises.

Furthermore, FGD was performed twice in the research area and involved approximately ten people for each FGD. Participants of the FGDs were recruited purposively from three categories of small-scale salt producers with different socio-economic backgrounds to ensure a representation of different groups and views. Participants were asked to discuss important issues regarding salt mining, such as problems and actual issues faced by salt producers during mining, sources and causes of uncertainty, and their responsive adaptation techniques to minimize the odd impacts of such events. Responses of all participants were recorded after asking for an informal verbal consent.

Respondents were selected randomly in Sampang District. In most cases, interviews were conducted with the head of the household, who are usually involved in most of the salt production work. Sampled respondents were divided into three categories based on land ownership, as we mention in section 2: (1) land owner; (2) wage laborer; and (3) tenant (see Table 2).

Table 2. Sample size and demographics

\begin{tabular}{lccccccccc}
\hline $\begin{array}{l}\text { Population of } \\
\text { small-scale salt } \\
\text { producers } \\
\text { (in particular } \\
\text { village of } \\
\text { Sampang) }\end{array}$ & $\begin{array}{l}\text { Respon } \\
\text { dent }\end{array}$ & \begin{tabular}{l} 
Land \\
\cline { 2 - 8 }
\end{tabular} & $\begin{array}{c}\text { Type of salt producers (\%) } \\
\text { owner }\end{array}$ & $\begin{array}{c}\text { Age } \\
\text { laborer }\end{array}$ & Tenant & Mode & Male & Education & Experiences \\
\hline 86 & 33 & 8 & 11 & 14 & $51-65$ & 96 & 23 & 21 \\
$(100 \%)$ & $(38 \%)$ & $(24 \%)$ & $(33 \%)$ & $(43 \%)$ & & & $(70 \%)$ & $(64 \%)$ \\
\hline
\end{tabular}

Source: Fieldwork, 2016

\subsection{Limitations of the study}

The study has some limitations. This survey does not cover the entire district or all salt 
producers. Our sample size is relatively small compared to the total salt production of each district in Indonesia. Hence, the conclusions drawn from this study are area-specific and may not be generalized for the entire province or country. Instead, the case study is designed to identify the adaptation practices for dealing with uncertainty in the specified areas.

\section{Frequency and impact of uncertainty events}

In this section, we attempt to explore the uncertainty events that have been faced by smallscale salt producers regarding the frequency and impact of uncertainty events. A fivepoint Likert scale was used to code their perceptions, in which "1" indicates "rarely (happens)" or "very low effect" and " 5 " stands for "always (happens)" or "very high effect."

During FGD, the attendees explained that, in their view, salt price fluctuation and excess rainfall rank first among uncertainty events in salt production practices because "fluctuation of salt prices and unpredicted rains have the strongest impact on their salt productions" (FGD, September 25, 2015). Other important events include floods, landslides, changing government regulation and lack of financial capital. The empirical results of FGD were verified and validated during the next field research performed in May 2016. Similar responses were given during the household survey.

Table 3. Small-scale salt producers' perceptions toward the frequency and effects of uncertainty events

\begin{tabular}{|c|c|c|c|c|c|c|c|c|c|c|c|}
\hline \multirow{3}{*}{$\begin{array}{c}\text { Salt } \\
\text { producers }\end{array}$} & \multirow{3}{*}{$\begin{array}{l}\text { Uncertainty } \\
\text { events }\end{array}$} & \multicolumn{5}{|c|}{ Frequency $(\%)$} & \multicolumn{5}{|c|}{ Effect (\%) } \\
\hline & & 1 & 2 & 3 & 4 & 5 & \multirow{2}{*}{$\begin{array}{c}1 \\
\text { Very } \\
\text { low } \\
\end{array}$} & 2 & 3 & 4 & \multirow{2}{*}{$\begin{array}{c}5 \\
\text { Very high }\end{array}$} \\
\hline & & Rarely & $\begin{array}{c}\text { Some- } \\
\text { times }\end{array}$ & Frequently & Often & Always & & Low & Medium & High & \\
\hline \multirow{6}{*}{$\begin{array}{l}\text { Wage } \\
\text { laborer } \\
(\mathrm{n}: 11)\end{array}$} & Rainfall & - & - & 36 & - & 64 & - & - & - & - & 100 \\
\hline & Flood & 55 & 45 & - & - & - & - & - & - & 55 & 45 \\
\hline & Landslide & 36 & 45 & - & 18 & - & - & - & 55 & 0 & 45 \\
\hline & Govt. Reg. & - & 36 & 45 & - & 18 & - & 36 & 45 & - & 18 \\
\hline & Salt Price & - & - & - & - & 100 & - & - & - & - & 100 \\
\hline & Fin. Cap. & - & - & - & 45 & 55 & - & - & 36 & 45 & 18 \\
\hline \multirow{6}{*}{$\begin{array}{l}\text { Tenant } \\
(\mathrm{n}: 14)\end{array}$} & Rainfall & - & - & 7 & 50 & 43 & - & - & - & - & 100 \\
\hline & Flood & 43 & 57 & - & - & - & - & - & - & 93 & 7 \\
\hline & Landslide & - & 57 & - & 43 & - & - & - & 100 & - & - \\
\hline & Govt. Reg. & - & - & 7 & 50 & 43 & - & - & - & - & 100 \\
\hline & Salt Price & - & - & - & - & 100 & - & - & - & - & 100 \\
\hline & Fin. Cap. & - & - & - & - & 100 & - & - & - & - & 100 \\
\hline
\end{tabular}




\begin{tabular}{|c|c|c|c|c|c|c|c|c|c|c|c|}
\hline \multirow{3}{*}{$\begin{array}{c}\text { Salt } \\
\text { producers }\end{array}$} & \multirow{3}{*}{$\begin{array}{l}\text { Uncertainty } \\
\text { events }\end{array}$} & \multicolumn{5}{|c|}{ Frequency $(\%)$} & \multicolumn{5}{|c|}{ Effect (\%) } \\
\hline & & 1 & 2 & 3 & 4 & 5 & \multirow{2}{*}{$\begin{array}{c}1 \\
\text { Very } \\
\text { low } \\
\end{array}$} & 2 & 3 & 4 & \multirow{2}{*}{$\frac{5}{\text { Very high }}$} \\
\hline & & Rarely & $\begin{array}{c}\text { Some- } \\
\text { times }\end{array}$ & Frequently & Often & Always & & Low & Medium & High & \\
\hline \multirow{6}{*}{$\begin{array}{l}\text { Land } \\
\text { owner } \\
(\mathrm{n}: 8)\end{array}$} & Rainfall & - & - & - & 100 & - & - & - & - & - & 100 \\
\hline & Flood & - & 100 & - & - & - & - & - & - & 100 & - \\
\hline & Landslide & - & 100 & - & - & - & - & - & 100 & - & - \\
\hline & Govt. Reg. & - & - & - & 100 & - & - & - & - & - & 100 \\
\hline & Salt Price & - & - & - & - & 100 & - & - & - & 25 & 75 \\
\hline & Fin. Cap. & - & 25 & - & - & 75 & - & - & - & - & 100 \\
\hline \multirow{6}{*}{$\begin{array}{l}\text { Total } \\
(\mathrm{n}: 33)\end{array}$} & Rainfall & - & - & 15 & 46 & 39 & - & - & - & - & 100 \\
\hline & Flood & 36 & 64 & - & - & - & - & - & - & 82 & 18 \\
\hline & Landslide & 12 & 64 & - & 24 & - & - & - & 85 & - & 15 \\
\hline & Govt. Reg. & - & 12 & 18 & 46 & 24 & - & 12 & 15 & - & 73 \\
\hline & Salt Price & - & - & - & - & 100 & - & - & - & 6 & 94 \\
\hline & Fin. Cap. & - & 6 & - & 15 & 79 & - & - & 12 & 15 & 73 \\
\hline
\end{tabular}

Source: Fieldwork, 2016

Results of the survey further revealed that households in the study area predominantly face uncertain situations. For instance, $100 \%$ of the sampled respondents perceived unexpected fluctuation of salt price as the primary risk, followed $80 \%$ of small-scale salt producers who regarded lack of financial capital as a major threat for salt mining (Table 3 ). Among other uncertain conditions faced by salt producers, excess rainfall, changing government regulations, landslides and floods were perceived as having a high impact on the mining activities in the study area. Those three actors have same perception about some uncertainty events, such as rainfall, flood, and fluctuation of salt price. However, there are significance differences about landslide, changing government regulation and lack of financial capital among three category of salt producers.

A majority of the tenant $(100 \%)$ and land owner (100\%) concern with the effect of changing government regulations, while only $18 \%$ of wage laborer cited the very high effect of changing government regulations. Moreover, tenant and land owner, expressed the lack of financial capital as being of great concern, while not for wage laborer. This answer indicates the effect of uncertainty events does affect salt producers unequally. For tenant, if they want to run a salt production, this is requiring adequate financial resources. Further, the greater concern for fluctuation of salt price, rather than for climatic uncertainty events, is consistent with evidence from other studies of farm communities and climate risk (Tucker et al., 2010; Eakin, 2005). The risk posed by volatile weather conditions is significant and particularly salient if a major climatic event has occurred in 
very recent memory, but climate risk is also well understood by agriculturalists.

\subsection{Fluctuation of salt price}

Data from Table 3 show that all respondents stated fluctuation of salt price is the most frequent uncertainty event occurring in the study area. During key informant interviews, the Chairman of Solidarity of Salt Producers in Sampang, SSS, noted that "the local price of salt has fluctuated because of an abundance of imported salt entering the country during the peak harvest period". Furthermore, FZN (tenant), said that small-scale salt producers are actually trying to maintain the selling price of salt by storing it in warehouses. However, because they do not have enough financial capital, their salt harvest had to be sold even at low prices: "We could not save the salt much longer because we need money for daily needs."

According to small-scale salt producer experience, the fluctuation of salt price negatively affects their livelihood and economic returns. Additionally, it may benefit a small group of middlemen and importers while reducing the interest of younger generations to become involved in salt production.

\subsection{Lack of financial capital}

Besides the fluctuation of salt price, based on the data from Table 3, the other uncertainty event is lack of financial capital. Access to formal loans for salt producers is limited. In Indonesia, a large percentage of the population has little or no access to financial services due to geographical, infrastructural and cost barriers. According to the International Finance Corporation (IFC, 2013; 2016), only 1.91\% of the farmers have outstanding loans with banks, whereas overall $17 \%$ of the Indonesian population borrows formally and only 20-34\% of rural households were estimated to have access to banking services.

Sampang has 221 village units of economic activities or Village Unit Cooperatives (KUD) with total membership of 20,852 people and business volume about of Rp. $104,071,828$. Unfortunately, those financial resources could not be utilized by salt producers because the procedure (requirements) for customers in order to grant them credit is complicated and amount offered is insufficient for land preparation and equipment purchase.

Consequently, most of them prefer to borrow money from a middleman. If salt producers take loans from salt-trading middleman, the procedure is easier than formal institution. The middleman offers credit without collateral, but the salt production must be sold to the middleman. A key informant, MIT, said that "the central government has a policy of providing loans for salt producers as well. But the formalities of government banks are 
complicated and they need collateral." Therefore, some of salt producers take loans from the salt-trading middlemen.

\subsection{Excess rainfall}

This survey also revealed that about $39.4 \%$ of salt producers' households said that the excess rainfall is one of the most frequent uncertainty events in Sampang. Based on data from the Indonesian Agency for Meteorology, Climatology, and Geophysics (2016), in Sampang, within ten years, annual rainfall measurement data shows that the distribution of minimal rainfall in the Sampang region was $889.9 \mathrm{~mm} / \mathrm{year}$ and the highest was 1,707.99 mm/year. The average annual rainfall in the Madura area was about 1,315.96 $\mathrm{mm}$ /year. Most areas in Sampang have low rainfall, which affects 116,292 ha or $95.2 \%$ the entire district of Sampang. Very low rainfall areas affect 5,189.5 ha, or 4.2\%, and areas with moderate rainfall measure only 691.9 ha or $0.6 \%$.

Average rainfall in Sampang is relatively low, but rain during salt season is always fatal for salt production because it can affect the density of salt water, resulting in a low yield. After raining, the salinity of condensers and crystallizers starts to decrease, so salt producers need to wait a few more days before harvesting. But continuous rain, even very low rainfall, makes the entire area unfavorable for salt production. The salt pans may also flood with rainwater, as they are shallow. There is also evidence that the number of rainy days in the last five years has fluctuated erratically based on the data from the Indonesian Agency for Meteorology, Climatology and Geophysics, as shown in Fig. 3. 


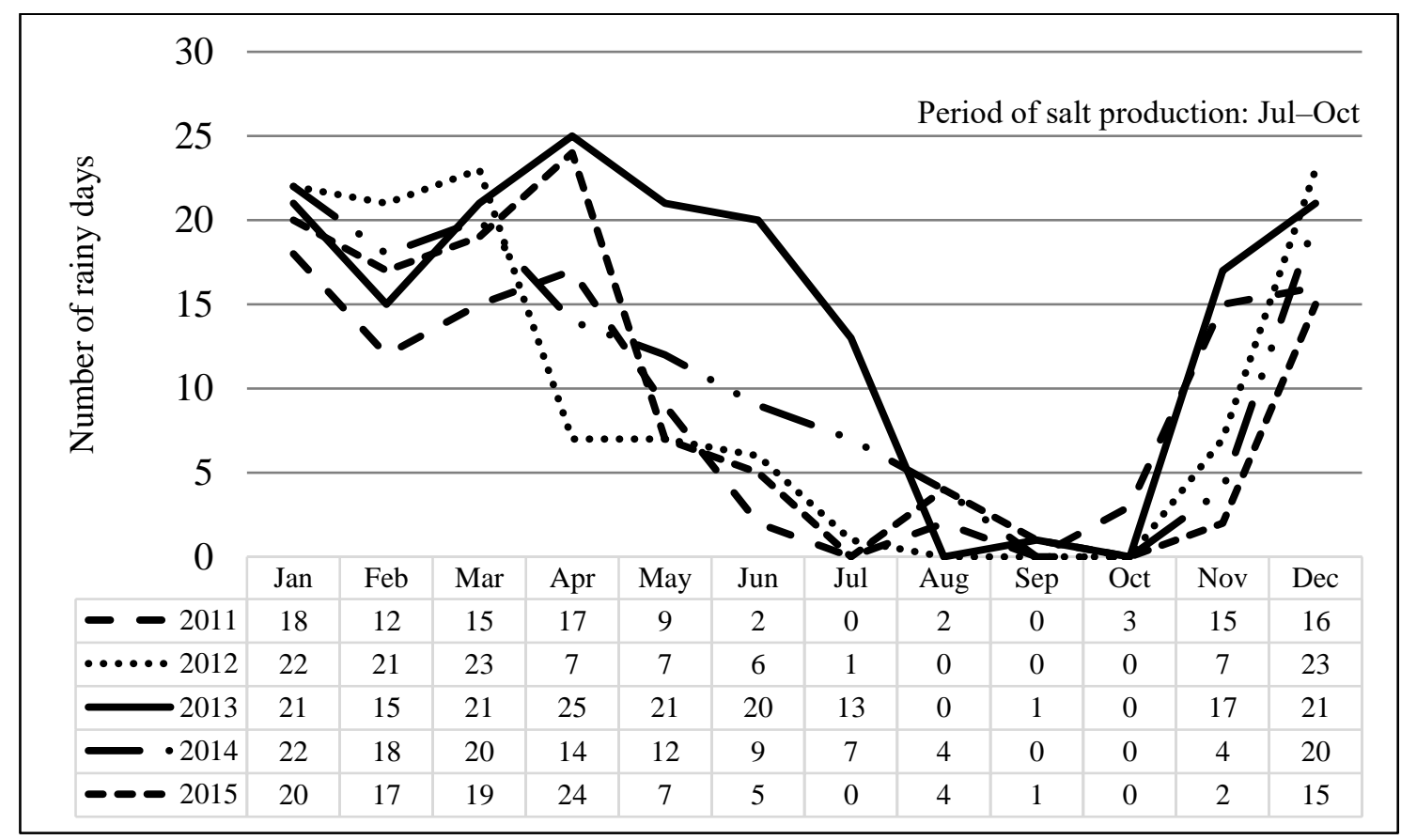

Fig. 3. Number of rainy days in Sampang in the last 5 years

Source: Indonesian Agency for Meteorology, Climatology and Geophysics (2016)

As can be seen in Fig. 3, on average, every year it rains for 10 days per month. In addition, the number of rainy days is greatest in 2013, which had 175 rainy days. In Sampang, where sea salt production is the primary economic activity, the impact of excess rainfall is observed in the form of poor economic returns via flooding of the salt beds and a decrease in production. Based on reports from the East Java Regional Disaster Management Agency (BPBD, 2013), rainfall in 2013 resulted in the flooding of some salt land areas. At least 2,950 metric tons of salt were flooded with water because of rain. Moreover, in a previous year (i.e., 2010), salt producers were only able to produce 7,820 metric tons of salt because of a prolonged rainy season in the region.

\subsection{Changing government regulation}

The survey also reported that changing government regulation is one of major uncertainty events in Sampang. These findings revealed that small-scale salt producers were concerned about the effect of the political situations in Indonesia on their salt production. In Indonesia, the rules relating to the salt trade have changed at least six times from 2004 to 2015 (Fig. 4). This means that, on average, a change in policy related to salt occurred once every 1.8 years. The regulation pertained to the salt issue price, quota of imported salt and salt industry. 


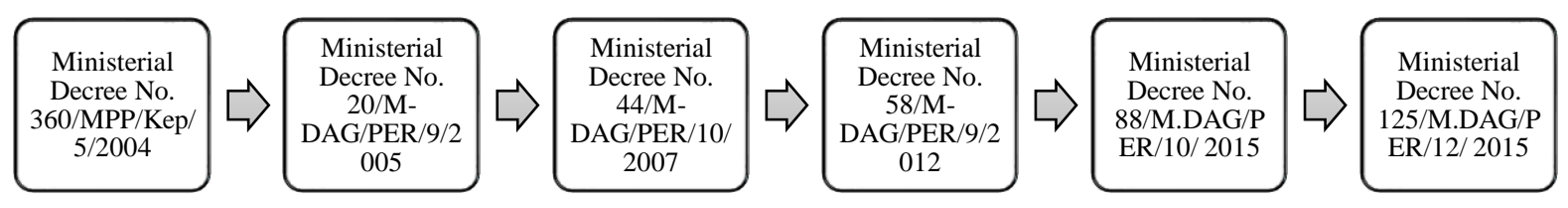

Fig. 4. Changing government regulation on salt trading system, from 2004 to 2015

The policy changing every year has brought consequences to the salt producers at the local level. This is because the regulations directly touch their production base. In the FGD, the chief of KPLTG (Kerukunan Pemilik Lahan Tambak Garam) Sampang revealed that "these policy changes bring serious implications for the survival of salt producers in Madura." This is because there are some changes in the regulation in which aspects that had formerly existed were removed from the current salt regulation. These aspects are presented in Table 4.

In Table 4, we can see if the Ministerial Decree No. 58/M-DAG/PER/9/2012 of government is to protect small-scale salt producers with one implementing the policy of administered prices $^{2}$ (base price of purchase), but contrary to the Ministerial Decree No. 125/M.DAG/PER/12/2015, which liberalized the salt trade in the market.

Table 4. Ministerial decrees of salt trading systems in Indonesia

\begin{tabular}{llc}
\hline Aspect & \multicolumn{1}{c}{$\begin{array}{c}\text { Ministerial Decree } \\
\text { No. 58/M-DAG/PER/9/2012 }\end{array}$} & $\begin{array}{c}\text { Ministerial Decree } \\
\text { No.125/M.DAG/PER/12/2015 }\end{array}$ \\
\hline Period of & - Salt imports are prohibited during peak harvest & None \\
salt & season, as well as 1 month before and 2 months after & \\
import & peak harvest season (article 3, verse 1); \\
& - Period of salt harvest season is decided by Ministry \\
& of Industry and Indonesian Meteorology, \\
& Climatology, and Geophysical Agency (BMKG) \\
& (article 3, verse 2) \\
\hline
\end{tabular}

\footnotetext{
2 Basic purchasing price level (administered). This price must take into account both producer and consumer. Some of things included are: (i) support prices - usually determined at the beginning of the producing process to guarantee salt producers; (ii) issue prices - to protect consumers, as they get a particular commodity at a lower price than the market price; and (iii) procurement prices - to ensure providing the main food commodities; usually, this price is determined and announced by the government.
} 


\begin{tabular}{|c|c|c|}
\hline Aspect & $\begin{array}{c}\text { Ministerial Decree } \\
\text { No. 58/M-DAG/PER/9/2012 }\end{array}$ & $\begin{array}{c}\text { Ministerial Decree } \\
\text { No.125/M.DAG/PER/12/2015 }\end{array}$ \\
\hline Salt price & $\begin{array}{l}\text { Salt price is decided by Ministry of Trade by } \\
\text { considering related institutions and associations (article } \\
4 \text {, verse } 1 \text { ) }\end{array}$ & None \\
\hline Quota & $\begin{array}{l}\text { Salt import quotas are decided by Ministerial } \\
\text { Coordination Meeting by considering production and } \\
\text { domestic consumption (article } 5 \text {, verse } 1 \text { ) }\end{array}$ & None \\
\hline $\begin{array}{l}\text { Salt } \\
\text { domestic } \\
\text { product }\end{array}$ & $\begin{array}{l}\text { Private companies (importers) can import salt so long as } \\
\text { they have permissions from Directorate General of } \\
\text { Foreign Trade (article } 2 \text { and article 9). Importers can } \\
\text { also import salt if they already purchase at least } 50 \% \\
\text { from domestic production (article } 6 \text {, verse } 1 \text { ). }\end{array}$ & $\begin{array}{l}\text { Imported salt can only be sold } \\
\text { by the appointed state-owned } \\
\text { enterprise (article 12) only in } \\
\text { the case whereby a harvest } \\
\text { failure occurs and/or the } \\
\text { availability of locally produced } \\
\text { consumption salt cannot meet } \\
\text { the demand (article 11) }\end{array}$ \\
\hline
\end{tabular}

Source: Author (2016)

Basic price policy, in general, is a form of collateral price that will be accepted by smallscale salt producers at harvesting time. It aims to make salt producers receive a decent price. The basic price was set by the government. Unfortunately, this policy has now been removed and the government prefers to use the market price.

\subsection{Landslides and floods}

The survey also reported that landslide and floods together create one of the major uncertainty events in Sampang. The occurrence of landslides and floods in Sampang has increased over the past decades, caused a number of effects and affected population.In 2016, about eight villages in Sampang were under approximately 2 meter of floodwater. According to the Disaster Information Manager (Pusat Pengendali Operasi) of the East Java Regional Disaster Management Agency (Badan Penanggulangan Bencana Daerah), in October 10, 2016, floods in Sampang affected 4,325 household. Water has flooded a number of roads and neighborhoods. ${ }^{3}$

\footnotetext{
${ }^{3} \mathrm{http} / /$ nasional.republika.co.id/berita/nasional/daerah/16/10/10/oeu6tt361-banjir-sampang-ketinggian-air-capai-2meter (accessed 31 December 2016).
} 


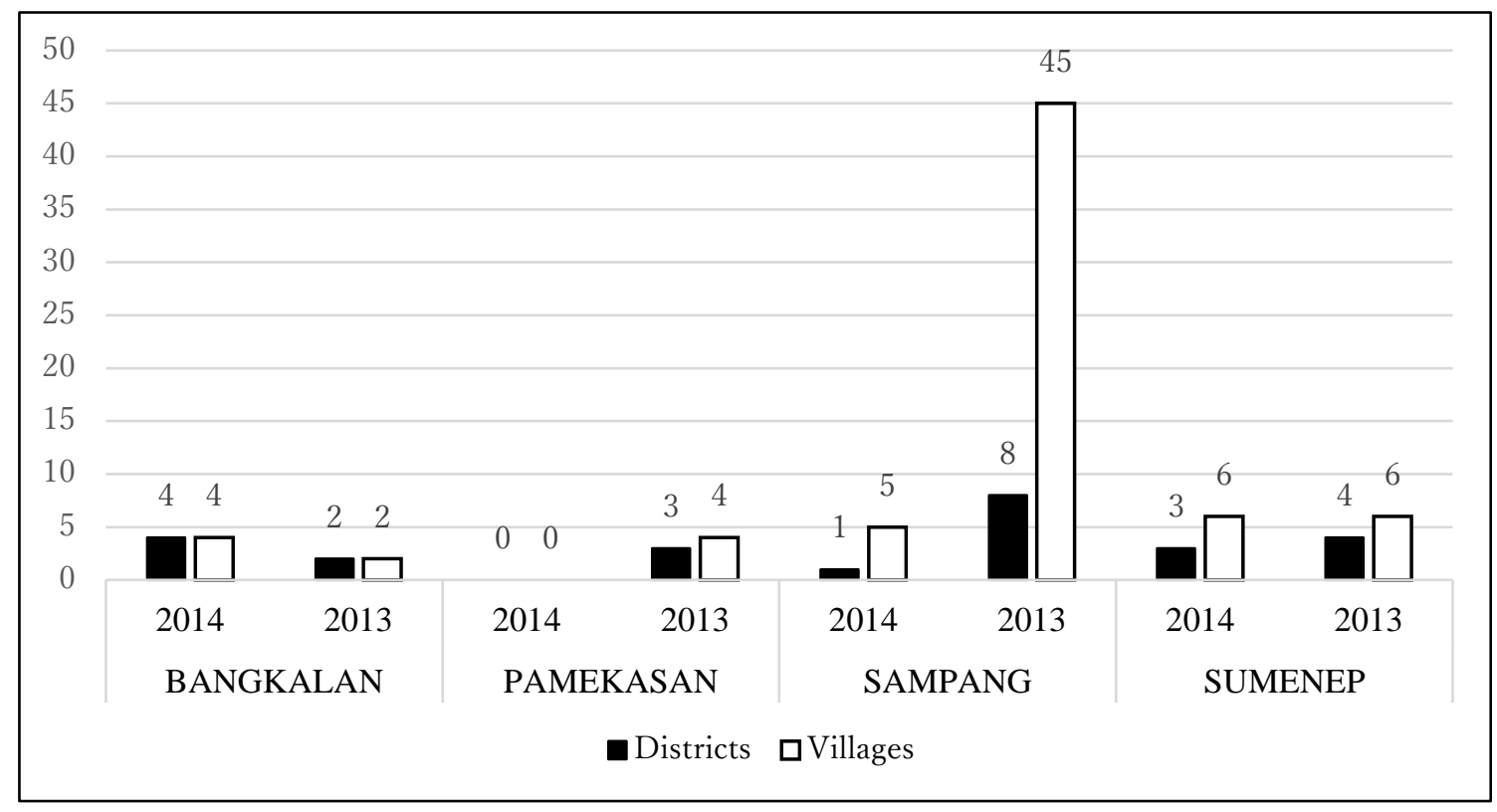

Fig. 5. Number of districts and villages affected by flooding

Source: BPBD (2016); compiled by author

Previously, floods also occurred in Sampang in 2013 and 2014. About 45 villages of eight districts were flooded in 2013, while in 2014 five villages in one district were flooded (see Fig. 5). In 2013, the average water level was about 2.5 meters, and water receded after three or four days. In 2014, the water was only knee-high and then receded. ${ }^{4}$

The key primary effects of landslides and floods in the Sampang region include loss of life and injuries, destruction of infrastructure, destruction of farm land and livestock, and destruction of property and business. In 2013, floods destroyed 403 hectares of farm and salt land, as well as three schools, and five people died, with total material losses estimated at Rp. 18 billion (BPBD, 2016).

\section{Dealing with uncertainty: salt producers' responses}

This section discusses how small-scale salt producers deal with uncertainty. The survey results suggest that the rest of the surveyed salt producers reported that they had undertaken a variety practices from the uncertainty event. At least, one strategy to manage the uncertainty events had occurred. Salt producers' response that we discussed in this chapter refers to specific efforts that the household deployed to manage, mitigate, tolerate, reduce or minimize stressful uncertainty events. In Sampang, there are many possible

\footnotetext{
${ }^{4}$ https://nasional.tempo.co/read/news/2016/02/28/058748964/terendam-banjir-2-5-meter-rri-sampang-berhentimengudara (accessed 31 December 2016).
} 
responses for dealing with these uncertainties, such as stocking up on salt, diversifying sources of income, relying social networks and adapting new technologies.

\subsection{Stocking up on salt}

Stocking up on salt is one of the strategies small-scale salt producers use to face the fluctuation of salt price. Out of 22 respondents (tenant and land owner), two people did this to deal with uncertainty events, especially to deal with fluctuation of salt price. However, this strategy is done by those who have storage capacity and enough financial capital to survive. This is because most small-scale salt producers need to release their products to the market due to the urgent daily needs of their family. BS, who has already worked as a salt producer for more than 20 years, explained:

\section{"I was forced to stock up on salt while expecting the salt price would rise}

during the next season, and I consider this salt to be my savings."

From 150 metric tons of salt production, as much as 130 metric tons is stored by BS. He explained that during peak harvest season, the salt price has always been interfered with middlemen (merchants). Therefore, during the peak harvest season, the salt price always drops drastically.

Among the surveyed salt producers, BS is one who has storage facilities. Thus, he did not have difficulty storing his salt products until the prices increased. The existence of adequate storage to keep salt stock is very important. If the storage is not good, the salt stock can be ruined by water during rainy season.

Different from BS, SL, a salt producer who works as a tenant, revealed that she was not able to store salt and wait until prices increase. This is because she has a debt to a middleman during the lean season (the rainy season). She owes to support her family during the rainy season because there is no income from the salt land. Thus, once salt season arrives then on salt harvesting season, she sells her product directly to middlemen at any price. From SL's case, we can see that stocking up salt is only applicable if the salt producers are free from the dependence on financial capital that is deliberately created by the middlemen.

For middlemen, it is good to buy salt from producers at harvest time due to cheap salt prices and abundant supply. After that, the lean season (rainy season) or a time of crisis will create the right momentum to be able to sell their salt stocks, because this is an opportunity to maximize their profits.

According to Burt (1992), when two players meet, for example a seller and a buyer, then the most advantaged are the middle of them. They are the middlemen because they can receive most of the margin or profit from a seller (salt producers) and buyer (salt factory). 
It is not disengaging from their position in the middle allows them to "play" both positions, seller and buyer, because they understand the conditions of two cultures, which are different from each other.

\subsection{Diversification of source of income}

Besides stocking up on salt, the salt producers in Sampang also diversify their sources of income to deal with uncertainty. Diversifying income sources is one of the most remarkable characteristics of rural livelihoods. Local communities that depend on natural resources for a livelihood often cope with the uncertainty of income by diversification (Adger et al., 2009; Helmi \& Satria, 2012; Ellis, 2000).

Ellis (2000) classifies the factors of deciding to diversify income into two broad categories: necessity vs. choice. Diversification by choice is related to the voluntary decision of a household to diversify. In this case, a household chooses to diversify not for survival per se but also for accumulation. Necessity-driven diversification, on the other hand, is the result of desperation, the last resort of a vulnerable household for survival. In this case, diversification may lead the household to end up in a more vulnerable livelihood system than the one that was adopted previously (Davies, 1996, cited in Ellis, 2000).

The majority of small-scale salt producers in Sampang fall into the necessity-driven diversification category. This is based on the respondents' explanations that they diversify their income just to meet daily needs (subsistence). For example, MK, has been involved in the salt business for the last 30 years. During that time, he was entrusted by the land owner to manage his salt ponds. In the rainy season, he was directed by the employer to change the salt ponds into shrimp ponds. The capital consisting of shrimp and milkfish (C. chanos) eggs were given by the land owner. Usually, around 5,000 shrimp and fish fingerlings are released. For a hatchery of 5,000 milkfish, MK needs approximately Rp. 150,000. He recalled that of those 5,000 fish hatchlings of shrimp and fish, at harvest time only about 100 to 500 fish remained. According to him, this is because many of them were lost through floods during the rainy season or stolen by people:

"During rainy season, usually I cultured shrimp and fish in the pond. But the result is usually not as much compared with the salt because many of fish died, were swept away by floods or were stolen. Usually in the rainy season, nobody watches the ponds, so sometimes people poach (steal) the fish. " - MK (interview May 22, 2016)

The income obtained from shrimp and fish ponds is far below that received from salt production. For example, MK sold the milkfish (C. chanos, in Indonesian, Bandeng) for 
Rp. 25,000 per kg. According to him, although the income is far less, it is enough to eat. At least he can harvest his shrimp and fish for his daily needs.

In addition to MK, there is SL, a woman who also worked 30 years as a salt producer and had to change her source of income during the rainy season. She worked as a farm laborer on land owned by neighbors, earning Rp. 30,000 per day. She was forced to work as a farm worker because there was no other kind of work that she could get. Besides working to produce salt, small-scale salt producers in Sampang also have jobs in other forms of work, such as fishing, construction, farming, aquaculture, daily wage labor and others, as presented in Table 5.

Table 5. Source of income diversification

\begin{tabular}{lccc}
\hline Source of income & Tenant (14) & Land owner (8) & Wage laborer (11) \\
\hline Construction & 14 & - & - \\
Aquaculture & 29 & 25 & - \\
Agriculture & 29 & - & 9 \\
Fishing & 7 & - & 18 \\
Daily wage & 14 & 38 & 45 \\
Livestock & - & 13 & - \\
Other & 7 & 25 & 27 \\
\hline
\end{tabular}

Source: Fieldwork (2016)

The majority of tenant (29\%) surveyed indicated aquaculture and agriculture activities as their main source of additional income. For land owner (38\%) and wage laborer (45\%), they indicated the daily wage labor as their main source of income. However, there are difference activity in terms of daily wage labor for land owner and wage laborer. For land owner, they sell his/her labor to the official institution (such as government, etc) and mostly under a formal contract. In contrast, for wage laborer, they sell his/her labor mostly under an informal contract.

For small-scale salt producers in Sampang, it is revealed that they prefer to work as daily wage laborers rather than maintain the pond or farm work, which has greater benefits and risks. According to $\mathrm{HH}$, compared to developing their own business, becoming a wage laborer is a less risky option with a guaranteed daily income.

As pointed out by Ellis (2000), income diversification as a risk strategy is often taken to imply a trade-off between a higher total income involving greater probability of income failure, and a lower total income involving smaller probability of income failure. In other 
words, households are considered to be risk averse, and for this reason are prepared to trade lower total income for greater income security.

\subsection{Relying social networks}

For dealing with uncertainty events, especially for advocating government regulation, small-scale salt producers also build social networks, both horizontal and vertical. As pointed out by Kusnadi (2000), the horizontal social relations may occur if the individual involved has equal or relatively similar socioeconomic status. In contrast, in the vertical social relations, the individuals involved have unequal socioeconomic status, regarding either their obligations or the resources that they exchange. Vertical social relations are realized in patron-client relationships.

Related to horizontal social relations, YT, revealed that small-scale salt producers in Sampang have established formal organizations, a salt community producers group, known by the acronym formed from its Indonesian name: KUGAR (Kelompok Usaha Garam Rakyat). The KUGARs consists of individual salt producers who group together (usually composed of 5 to 10 salt producers) to carry out salt production. According to data from the Regional Office of Marine and Fisheries Affairs in Sampang, there are at least 47 KUGAR groups in Sampang. These groups are formed so salt producers have a strong bargaining position in dealing with all sorts of obstacles and barriers.

At the time of implementation of the Ministerial Decree of the Ministry of Trade No. $58 / \mathrm{M}-\mathrm{DAG} / \mathrm{PER} / 9 / 2012$, the role of these groups is vital because every month they collect generated data of salt production and how much is purchased by salt companies. Such purchasing is done per the regulations in the Ministerial Decree No. 58/MDAG/PER/9/2012 because salt companies are obliged to buy salt from domestic producers if they want to import salt from abroad. Today, the role of KUGAR was gradually changed. These groups have helped to facilitate technology transfer among salt producers. For those who want to get government support, like geomembrane or small credit, they have to be a member of KUGAR.

Moreover, besides the formal bonds discussed above, some research also shows that all salt-producing household claimed to have informal social networks. According to Stone, (2001), these informal social networks indicate that trust and reciprocity exist which are more familiar and personal. Familiar and personal linkages make social relations between households become closer. Thus, these social relations will be beneficial for exploring collective efforts to optimize the existing resources in order to improve the household welfare of small-scale salt producers in Sampang. 
As pointed out by Hongest (2005), informal institutions and private social networks play three distinct roles (cited in Deressa et al., 2009). First, they act as conduits for financial transfers that may relax the farmer's credit constraints. Second, they act as conduits for information about new technology. Third, social networks can facilitate cooperation to overcome collective action dilemmas, where the adoption of technologies involves externalities.

In Sampang, many salt producers also use this network to exchange information as well as goods and services. YT explained that by using both informal and formal social networks, they can access loans during the lean season or when not producing salt and can access government aid or programs.

\subsection{Adopting new technology: using a geomembrane}

The most common of these consequential uncertainty events was a reduction in salt productions profit. MT, a tenant who has already worked as a salt producer for more than 25 years, argue that adopting new technology may help them deal with the impact of uncertainty events.

This study shows that the salt producers in Sampang adopting new technology by using geomembrane. A geomembrane is a synthetic membrane liner or barrier with very low permeability used with any geotechnical engineering-related material so as to control fluid (or gas) migration in a human-made project, structure or system. A geomembrane is made from relatively thin continuous polymeric sheets and is used to prevent the mixing of salt with the ground. This practice is done to reduce impurities that are usually mixed in conventional salt production and for dealing with landslides.

MT reported that the application of geomembrane technologies may increase salt production and prevent a landslide. However, most salt producers cannot afford to buy these items because too expensive. According to him, using a geomembrane requires at least Rp. 25 million. Moreover, there are other costs such as installation and maintenance so that the tool is only owned by land owners or middlemen.

The government, through the Ministry of Marine and Fisheries Affairs also provide geomembranes for small-scale salt producers. Unfortunately, only a few people are able to obtain such assistance. According to FUZ, a tenant, the aid is usually distributed by the government to small-scale salt producers. After that, the head of the KUGAR will decide to whom it is intended first.

Although technologies like geomembrane are no panacea, they are likely to be central to reducing vulnerabilities and building resilience to current climate variability and extremes. There is broad consensus on this in the literature, among practitioners and in 
international climate change discussions. The decisions adopted under the United Nations Framework Convention on Climate Change over the past 5-8 years reflect an increased attention to and recognition of the potential role of technologies and their transfer for adaptation (UNFCCC, 2015).

\subsection{Strengths and weaknesses of each response}

This study found, in the view of the salt producers, such responses may produce negative externalities, potentially increasing impact on others or reducing their capacity to adapt. During the FGD, the participants share their perception of advantages and disadvantages of each response, as shown in Table 6.

For example, the participant of FGD reported that using a geomembrane to cover uncertainty of salt production could increase marketing risk. This is because, although the geomembrane is likely to be more productive, there may be a higher risk of price fluctuations. Moreover, salt producers also reported that the decision to stock up on salt production is often focused on spreading the risk of price fluctuations over the season. It may, for example, ignore the cost of the response, such as local resources, market fluctuation and changing government regulation of the salt price. Thus, this response could result in a decrease in gross revenue if prices are less than expected.

Table 6. Advantages and disadvantages of each response

\begin{tabular}{|c|c|c|}
\hline Responses & Positive aspect (Strengths) & Negative aspect (Weaknesses) \\
\hline $\begin{array}{l}\text { Stocking up } \\
\text { on salt }\end{array}$ & $\begin{array}{l}\text { - Spreads the risk of price } \\
\text { fluctuations over the season } \\
\text { - Could stabilize income }\end{array}$ & $\begin{array}{l}\text { - Could result in a decrease in gross } \\
\text { revenue if prices are less than expected } \\
\text { - Results in an increase in storage cost } \\
\text { - Requires adequate financial resources } \\
\text { - Results in storage losses of stored } \\
\text { produce }\end{array}$ \\
\hline $\begin{array}{l}\text { Diversification } \\
\text { of livelihood }\end{array}$ & $\begin{array}{l}\text { - Reduction in income variability } \\
\text { Can ensure adequate cash flow, debt } \\
\text { obligations \& family living } \\
\text { expenses }\end{array}$ & $\begin{array}{l}\text { - If the commodity is interrelated, risk } \\
\text { may not be reduced }\end{array}$ \\
\hline $\begin{array}{l}\text { Social } \\
\text { network }\end{array}$ & $\begin{array}{l}\text { - Social obligation to assist the most } \\
\text { vulnerable } \\
\text { - Economy of information collection } \\
\text { and dissemination }\end{array}$ & $\begin{array}{l}\text { - Risks suffered by the whole community } \\
\text { are not mitigated }\end{array}$ \\
\hline
\end{tabular}




\begin{tabular}{lll}
\hline Responses & Positive aspect (Strengths) & Negative aspect (Weaknesses) \\
\hline Adapting new & - Could result in higher productivity & - Could result in an increase in costs of \\
technologies & - Could make more cost-effective use & production \\
& of inputs & - Requires adequate financial resources \\
\hline
\end{tabular}

Source: FGD in Sampang (25 May 2016)

However, the effectiveness of adaptation measures which rely on individual actions may therefore be very difficult to assess. In practice, there may be considerable uncertainty over the impact of an adaptation action. In some cases, the impact may be clear and immediate, and past experience may be a very useful guide. In other cases, for example where the action is innovative, the consequences may not be known. Our finding underlines the challenges of developing an integrated approach to mitigate these uncertainty events.

\section{Conclusions and policy implications}

Our study indicates that socio-economic and climate-related uncertainty events in smallscale salt producers in rural Sampang is becoming increasingly precarious. The changing government regulation, lack of financial capital and the fluctuation of salt price because of an abundance of imported salt have created an atmosphere of profound uncertainty and caution at the local level. At the same time, climate-related uncertainty events (excess rainfall, landslides and floods) affect their daily struggle to maintain some standard of living for themselves and their families.

Those three actors have same perception about some uncertainty events, such as rainfall, flood, and fluctuation of salt price. However, there are significance differences about landslide, changing government regulation and financial capital among three category of salt producers. These answers, in fact, shows the power relations and dynamics within the salt industry. For tenant and land owner, changing government regulation and lack of financial capital will affect seriously to their production. Government regulation will affect their strategy to sell or stocking-up their production. Thus, it will determine their profitability. Moreover, lack of financial capital for tenant and land owner cause losses in salt production and assets. This supports Adger et al. (2009) proposition that “...environmental and social change does not affect everyone equally. Less resilient communities - and more vulnerable individuals - can be severely affected by change, thus limiting their opportunities for adaptation”. This also support Brooks et al. (2005), Pelling \& High (2005), Adger et al. (2007), and Adger \& Jordan (2009) arguments that 
vulnerability and adaptation strategies to uncertainty events is usually inversely related to people's ability to access resources, assets and means of protection.

Evidence from this study also shows that each adaptation responses to the particular uncertainty event have advantages and disadvantages, however, this represents a dilemma of salt producers, potentially increasing impact on others or reducing their capacity to adapt. As pointed out by Adger et al. (2006), responses to change have uneven outcomes and inherently conflicting interests where particular adjustment strategies by an individual or a group may have consequences for the vulnerability and availability of adjustment options for others.

Furthermore, the relationship between uncertainty events and the responses of small-scale salt producers may be non-specific, that is, livelihood diversification may not determine, because a specific uncertainty occurs at a specific time. Thus, the ultimate achievement a successful adaptation to deal with uncertainty- is still a distant goal. However, by identifying small-scale salt producers' responses generally associated with uncertainty events, we may be able to help rural policymakers that rural community development programs must be in line with community actions.

Given that it is difficult to look at adaptation formation, we believe that more longitudinal studies of how small-scale salt producers' adaptation changes over time, especially after some individuals are exposed to randomized interventions, have the potential to be a fruitful area of future research. Finally, our finding underlines the challenges of developing an integrated approach to mitigating these uncertainty events. Such knowledge would contribute to designing and implementing policies and program that encourage beneficial adaptations. From the basis of these case studies, our results suggest that such policy responses should be nuanced. Policies need to fit diverse local contexts and perceptions. No single policy prescription is likely to meet the range of experiences and conditions on the ground.

\section{Acknowledgement}

This study is part of research toward a master's degree at the Department of Human Sciences, Graduate School of Letters, at Hokkaido University in Japan. The first author would also like to thank the Japanese Ministry of Education, Sport and Technology (MEXT) for providing scholarship support for pursuing master's degree. We are grateful to Prof. Taisuke Miyauchi, Mr. Wahid Ulah and Dr. Isma Rosyida for their valuable comments on an earlier version of this paper. We also thank two anonymous reviewers whose insightful comments on the manuscript substantially improved the scientific quality of this paper. 


\section{References}

Adger, W.N., S. Agrawala, M.M.Q. Mirza, C. Conde, K.L. O'Brien, J. Pulhin, R. Pulwarty, B. Smit and K. Takahashi. (2007). Assessment of adaptation practices, options, constraints and capacity. In: Parry, M.L. Canziani, O.F., Palutikof, J.P., Hanson, C.E., van der Linden P.J., (eds.) Climate Change 2007.: Impacts, Adaptation, and Vulnerability. Contribution of Working Group II to the Fourth Assessment Report of the Intergovernmental Panel on Climate Change. Cambridge University Press: Cambridge, pp. 719-743.

Adger, W. N., Hughes, T. P., Folke, C., Carpenter, S. R., \& Rockstrom, J. (2005).

Social-Ecological Resilience to Coastal Disasters. Science, 309(5737), 1036-1039. https://doi.org/10.1126/science.1112122

Adger, W. N., \& Jordan, A. (Eds.). (2009). Governing Sustainability. Cambridge: Cambridge University Press. https://doi.org/10.1017/CBO9780511807756

Adger, W. N., Lorenzoni, I., \& O’Brien, K. (2009). Adaptiong now. In W. N. Adger, I. Lorenzoni, \& K. L. OBrien (Eds.), Adapting to climate change: thresholds, values, governance (pp. 212-226). Cambridge: Cambridge University Press. Retrieved from http://www.muthar-alomar.com/wp-content/uploads/2013/01/Adopting-toClimate-Change.pdf

Agrawal, A., McSweeney, C., \& Perrin, N. (2008). Local Institutions and Climate Change Adaptation. Social Development Notes (Vol. 81). Washington, DC. Retrieved from https://openknowledge.worldbank.org/handle/10986/11145

Bacon, C. (2005). Confronting the coffee crisis: Can Fair Trade, organic, and specialty coffees reduce small-scale farmer vulnerability in Northern Nicaragua? World Development, 33(3), 497-511. https://doi.org/10.1016/j.worlddev.2004.10.002

Blaikie, P., Terry, C., Ian, D., \& Ben, W. (2005). At risk: natural hazards, people's vulnerability and disasters. London: Routledge.

Brooks, N., Adger, W. N., \& Kelly, P. M. (2005). The determinants of vulnerability and adaptive capacity at the national level and the implications for adaptation. Global Environmental Change, 15(2), 151-163. https://doi.org/10.1016/j.gloenvcha.2004.12.006

Deressa, T. T., Hassan, R. M., \& Ringler, C. (2011). Perception of and adaptation to climate change by farmers in the Nile basin of Ethiopia. The Journal of Agricultural Science, 149(1), 23-31. https://doi.org/10.1017/S0021859610000687 
Deressa, T. T., Hassan, R. M., Ringler, C., Alemu, T., \& Yesuf, M. (2009).

Determinants of farmers' choice of adaptation methods to climate change in the Nile Basin of Ethiopia. Global Environmental Change, 19(2), 248-255. https://doi.org/10.1016/j.gloenvcha.2009.01.002

Eakin, H. (2000). Smallholder maize production and climatic risk: A case study from Mexico. Climatic Change, 45(1), 19-36. https://doi.org/10.1023/A:1005628631627

Eakin, H. (2005). Institutional change, climate risk, and rural vulnerability: Cases from Central Mexico. World Development, 33(11), 1923-1938. https://doi.org/10.1016/j.worlddev.2005.06.005

Ellis, F. (2000). Rural Livelihood Diversity in Developing Countries. OUP Oxford.

Füssel, H. M., \& Klein, R. J. T. (2006). Climate change vulnerability assessments: An evolution of conceptual thinking. Climatic Change, 75(3), 301-329. https://doi.org/10.1007/s10584-006-0329-3

Hansen, J., Sato, M., \& Ruedy, R. (2012). Perception of climate change. Proceedings of the National Academy of Sciences, 109(37), E2415-E2423. https://doi.org/10.1073/pnas.1205276109

Hassan, R., \& Nhemachena, C. (2008). Determinants of African farmers' strategies for adapting to climate change: Multinomial choice analysis. AfJARE, 2(1), 83-104. https://doi.org/10.1007/s00267-008-9197-0

Hazell, P. B., \& Rahman, A. (Eds.). (2014). New directions for smallholder agriculture. OUP Oxford.

Helmi, A., \& Satria, A. (2012). Fisher's Adaptation Strategies to Ecological Changes Abstract. Makara Hubs-Asia, 16(1), 68-78. https://doi.org/10.7454/mssh.v16i1.1494

IFC. (2013). Indonesia Agri-finance. Retrieved from http://www.ifc.org/wps/wcm/connect/443a6f00408d25feb13ab1cdd0ee9c33/EAPIndonesia+Agri-finance.pdf?MOD=AJPERES.

IFC. (2016). Mobile Banking in Indonesia. Retrieved from http://www.ifc.org/wps/wcm/connect/1a5695804723d0248b21ab2b131bed2a/ Mobile\%2BBanking\%2BFinal\%2BReport.pdf?MOD=AJPERES.

IPCC. (2001). Climate change 2001 : Impacts, Adaptation, and Vulnerability. Cambridge University Press, 1-94. Retrieved from https://www.ipcc.ch/ipccreports/tar/wg2/pdf/wg2TARchap1.pdf 
Kesa, L., \& Fraiture, C. (2016). Farmers' Perspectives on Risk and Adaptation Strategies in the Mekong, Cambodia. Journal of Geography, Environment and Earth Science International, 5(3), 1-14. https://doi.org/10.9734/JGEESI/2016/23523

KKP. (2015). Produksi Garam Indonesia, 1-9. Retrieved from http://statistik.kkp.go.id/sidatik-dev/Berita/Analisis Produksi Garam Indonesia.pdf

Kurniawan, T., \& Azizi, A. (2012). Climate Change Impact on Salt Ponds Farmers in Sampang and Sumenep Districts. Jurnal Masyarakat Dan Budaya, 14(3), 499-518. Retrieved from http://jmb.lipi.go.id/index.php/jmb/article/viewFile/103/84

Leichenko, R., \& O’Brien, K. (2008). Environmental change and globalization: Double exposures. New York: Oxford University Press. https://doi.org/10.1093/acprof:oso/9780195177329.001.0001

Lund, C. (2014). Of What is This a Case?: Analytical Movements in Qualitative Social Science Research. Human Organization, 73(3), 224-234. https://doi.org/10.17730/humo.73.3.e35q482014x03314

Manyena, S. B. (2006). The concept of resilience revisited. Disasters, 30(4), 433-450. https://doi.org/10.1111/j.0361-3666.2006.00331.x

Mehar, M., Mittal, S., \& Prasad, N. (2016). Farmers coping strategies for climate shock: Is it differentiated by gender? Journal of Rural Studies, 44, 123-131. https://doi.org/10.1016/j.jrurstud.2016.01.001

Morton, J. F. (2007). The impact of climate change on smallholder and subsistence agriculture. Proceedings of the National Academy of Sciences, 104(50), 1968019685. https://doi.org/10.1073/pnas.0701855104

OECD. (2014). Climate Resilience in Development Planning : Experiences in Colombia and Ethiopia. https://doi.org/10.1787/9789264209503-en

Pelling, M., \& High, C. (2005). Understanding adaptation: What can social capital offer assessments of adaptive capacity? Global Environmental Change. https://doi.org/10.1016/j.gloenvcha.2005.02.001

Rigg, J., Salamanca, A., \& Thompson, E. C. (2016). The puzzle of East and Southeast Asia's persistent smallholder. Journal of Rural Studies, 43, 118-133. https://doi.org/10.1016/j.jrurstud.2015.11.003

Rochwulaningsih, Y., Sejarah, J., \& Semarang. (2017). Petani Garam dalam Jeratan Kapitalisme: Analisis Kasus Petani Garam di Rembang, Jawa Tengah.

Smit, B., Burton, I., Klein, R. J. T., \& Wandel, J. (2000). An Anatomy of Adaptation to 
Climate Change and Variability. Climatic Change, 45(1), 223-251. https://doi.org/10.1023/A:1005661622966

Stone, W. (2001). Measuring social capital: Towards a theoretically informed measurement framework for researching social capital in family and community life. Australian Institute of Family Studies, 52(24), 1-35. https://doi.org/ISSN $1440-4761$

Tucker, C. M., Eakin, H., \& Castellanos, E. J. (2010). Perceptions of risk and adaptation: Coffee producers, market shocks, and extreme weather in Central America and Mexico. Global Environmental Change, 20(1), 23-32. https://doi.org/10.1016/j.gloenvcha.2009.07.006

UNFCCC. (2015). Report of the Conference of the Parties on its twentieth session, held in Lima from 1 to 14 December 2014 (Vol. 1821). https://doi.org/10.1093/iclqaj/24.3.577 